\title{
Recombinant DNA hazards may be reassessed
}

A new basis on which to assess the probable hazards of recombinant DNA experiments and so determine the levels of containment at which they should be carried out is being considered by the UK Genetic Manipulation Advisory Group (GMAG). If accepted by both GMAG and the Secretary of State for Education and Science they would result in some experiments being downgraded, whereas others, now being carried out at minimum levels of containment, would need to be upgraded.

At present, containment levels both in the NIH and UK guidelines are broadly determined by the evolutionary relatedness of the cloned DNA to human DNA. Experiments involving bacterial DNA cloned in $E$. coli, unless it comes from pathogenic bacteria, may usually be carried out under minimum containment. Similar experiments with mammalian DNA require higher containment. Within each class of experiment the use of increasingly disabled hosts and vectors and increasingly pure DNA may allow lower levels of containment.

However, many inconsistencies in this blanket evolutionary approach have been pointed out. The new pro- posals, mentioned at a recent meeting of the Biochemical Society in London, rely instead on an individual assessment of the probable hazard in each case. Although no details of the proposals have been announced it seems that they would have to take into account such factors as: the probability of survival of the host/vector system outside the laboratory; the probability of transfer of the recombinant plasmid to other bacteria; the probability of the DNA's containing a harmful gene; the probability that the genes carried on the recombinant plasmid could be expressed; and the probability that their expression would be harmful. The final probability of a harmful outcome would then determine the containment level needed.

Meanwhile the US National Institutes of Health revised guidelines are at present with Joseph Califano, the US Secretary of Health and Welffare, for review. And while they involve a number of exceptions and exemptions from the original $\mathrm{NIH}$ regulations, they are still based on a concept of evolutionary distance between the DNA involved and human DNA.

Eleanor Lawrence

\section{US and China agree to expand science ties}

THE People's Republic of China has set up a national commission with broadranging responsibilities for all aspects of science and technology policy, in line with the new regime's decision to make scientific and technological development one of the four main goals of government policy. It will be responsible for monitoring, co-ordinating and setting priorities and budgets for scientific and technological research. It will cover the activities of scientific academies, research institutions, and government ministries.

The head of the new commission, $\mathrm{Mr}$ Fang Yi, led a group of Chinese science administrators which held a series of meetings in Peking last week with an official government delegation of their US counterparts, headed by Dr Frank Press, director of the Office of Science and Technology Policy.

On his return to Washington, $\mathrm{Dr}$ Press said that the talks had been "serious, friendly, and provided a promising basis for future co-operation." The latter could include the exchange of data, advanced seminars, cooperative research projects, "and a growing commercial relationship in the civilian, technical sector."

Dr Press said that the visit of the US delegation, which included the research heads of all the main government civilian agencies, was not meant as a gesture to the USSR, but was an attempt to establish the same type of relationship with China as the US currently enjoys with other countries.

During the visit, Mr Fang $\mathrm{Yi}$ told the US delegation that although there had been some increase in contact between scientists of the two countries since the signing of the Sino-Shanghai Communiqué of 1972, this was not enough. "New possibilities for Sino-US scientific and technological exchanges and co-operation need to be explored. We should make bigger strides and open wide avenues," he said.

Greater scientific and technological co-operation was "in the interests of both our sides and in accord with the desire of the people of the world to combat hegemonism," Mr Yi said.

David Dickson

\section{Europe evaluates Seasat}

EUROPEAN oceanographers and geodesists are collaborating with their American counterparts in assessing the usefulness of Seasat-A, the first purely oceanographic satellite launched by NASA at the end of last month. The European Space Agency is concerned at the possible cost of processing the enormous amount of data that the satellite will produce. For ESA, therefore, Seasat's evaluation phase is a time for assessing the satellite's value to Eupropean users before committing funds to building an expensive data processing facility.

So far two European experiments are involved in evaluating three of Seasat's four microwave experiments. They are JASIN, the joint air/sea interaction experiment; and a system of mobile doppler and tracking stations situated throughout Europe. Fourteen research vessels and aircraft are taking part in the former. They are making seasurface measurements in the north Atlantic as a contribution to the International Decade of Ocean Exploration and their measurements can easily be compared with those taken by Seasat. The latter are assisting in the calibration of Seasat's instruments by determining the satellite's altitude to within $10 \mathrm{cms}$.

The fourth microwave instrument on board is a synthetic aperture radar - the first such instrument to go up in a satellite. It will provide all-weather high resolution (about $25 \mathrm{~m}$ ) images of ocean waves, ice fields, icebergs and coastal conditions. As its data rate is very high (110 million bits per sec) it can only be operated in real time when data can be received by one of the tracking stations equipped to handle it (three are in the US, one is in Canada and one, owned by the European Space Agency, is at Oakhanger in the UK).

Seasat users in Europe are hoping to contribute to the evaluation phase of the synthetic aperture radar (SAR). They have already proposed seven possible experiments, of which they are sure that JASIN will be acceptedwork on that will start soon.

The vast amount of data produced by the SAR makes its processing costly and time consuming. Computers at the Jet Propulsion Laboratory, where all the data is being processed, can only analyse $1 \mathrm{sec}$ worth of data in $1 \mathrm{hr}$ of computer time. If European users want to make use of SAR data during Seasat's application phase they will have to make provision for analysing the raw data and that could mean building a special data processing facility at an estimated cost of 1.5 mau.

Judy Redfearn 